\title{
Efecto de la adición de nanofibras de carbono en las propiedades mecánicas y de durabilidad de materiales cementantes
}

\section{Effect of carbon nanofiber addition in the mechanical properties and durability of cementitious materials}

\author{
O. Galao(*), E. Zornoza ${ }^{(*)}$, F. J. Baeza ${ }^{(*)}$, A. Bernabeu(*), P. Garcés ${ }^{(*)}$
}

Recepción/Received: 11-III-11 Aceptación/Accepted: 23-IX-11

\section{RESUMEN}

En este artículo se han estudiado los cambios en las propiedades mecánicas de los morteros de cemento Portland debido a la adición de nanofibras de carbono (NFC). Se han determinado las resistencias a flexotracción y a compresión de los morteros en relación a la cantidad de NFC añadidas a la mezcla, al tiempo de curado y a la porosidad y densidad de los mismos. Además se han investigado los niveles de corrosión de barras de acero embebidas en pastas de cemento con NFC expuestos al ataque por carbonatación y por ingreso de cloruros. El aumento en el porcentaje de NFC añadido se traduce en un aumento la intensidad de corrosión registrada y una mejora de las propiedades mecánicas.

Palabras clave: nanofibras de carbono, cemento, propiedades mecánicas, durabilidad, corrosión.

\section{SUMMARY}

This paper reports on recent work that is directed at studying the changes in the mechanical properties of Portland cement based mortars due to the addition of carbon nanofiber (CNF). Both flexural and compression strength has been determined and related to the CNF addition to the mix, to the curing time and to the porosity and density of the matrix. Also, corrosion of embedded steel rebars in CNF cement pastes exposed to carbonation and chloride attacks has been investigated. The increase in CNF addition implies higher corrosion intensity and higher levels of mechanical properties.

Keywords: carbon nanofibers, cement, mechanical properties, durability, corrosion.

\section{INTRODUCCIÓN}

Actualmente la demanda de estructuras "inteligentes", capaces de detectar determinados estímulos y responder a ellos de forma adecuada, ha provocado que no solo se busque emplear materiales de construcción con buenas propiedades mecánicas y de durabilidad, sino que se

\section{INTRODUCTION}

Today's demand of "smart" structures, able to detect stimulus and respond adequately, has created the need of materials with not only good mechanical properties and durability, but the aim of new additional functions. And that is why many research lines have been focused

(*) Universidad de Alicante, Alicante (España). 
persigue utilizar materiales con otras funciones añadidas. Por ello en los últimos años muchas líneas de investigación trabajan en el desarrollo de materiales multifuncionales que combinen propiedades estructurales y funcionales (1-11).

La multifuncionalidad consiste en aprovechar el propio material estructural para realizar otras funciones no estructurales, sin necesidad de ningún tipo de dispositivo externo. De esta forma se reduce el coste, se simplifica el diseño, mejora la durabilidad, aumenta el volumen funcional, puesto que la función la lleva a cabo toda la estructura, y se minimiza la degradación de las propiedades mecánicas que normalmente ocurre al usar dispositivos embebidos.

Las propiedades funcionales incluyen la función de percepción de deformación $(1,2)$, percepción de daño (9), sensor de temperatura, control térmico (4), reducción de vibraciones (10) y reflexión de ondas electromagnéticas $(8,11)$. La multifuncionalidad se consigue incorporando al composite de matriz cementicia distintas adiciones, como materiales carbonosos conductores, que deben conferirle propiedades funcionales manteniendo o incluso mejorando sus características estructurales y que sean compatibles con una variedad amplia de distintas matrices cementicias $(12,13)$.

Entre los materiales empleados como adición para crear materiales multifuncionales se encuentran las nanofibras de carbono (NFC). El estudio y desarrollo de los composites de matriz cementicia que contienen NFC abre una nueva vía para la obtención de materiales multifuncionales, posiblemente más eficaces y con mayores campos de aplicación que los empleados actualmente.

Sabido es que uno de los mayores retos a los que se enfrenta el estudio de matrices basadas en nanopartículas de carbono es la dispersión de estas y, en particular, las NFC en matrices cementicias. Las NFC poseen excepcionales propiedades mecánicas, eléctricas y térmicas. Sin embargo, tienden a unirse debido a las fuerzas de van der Waals, formando aglomerados difíciles de separar, lo que implica la pérdida de buena parte de las propiedades constitutivas del nuevo material compuesto hasta incluso llegar a empeorar las del material original. Los grandes avances en matrices poliméricas con nanofibras de carbono no se han trasladado equitativamente a las matrices cementicias, en buena parte debido a este problema de dispersión.

Los métodos empleados para tal fin van desde el uso combinado de surfactantes y sonicado, la modificación superficial de las nanofibras, funcionalización (incorporación de grupos moleculares a la superficie de la fibra que mejoren su afinidad con la matriz) (14), hasta incluso el crecimiento de las nanofibras de carbono directamente on the development of multifunctional materials which combine both structural properties and functional applications (1-11).

Multifunctionality consists in using the structural material for new applications, beside the structural features, with no external devices. This property reduces costs, simplifies the design, improves durability, increases functional volume because the function is made by the whole structure, and minimizes the deterioration of the mechanical properties that usually occurs when using embedded devices.

The functional properties include self-strain sensing function (1-2), damage sensing (9), temperature sensors, thermal control (4), vibration reduction (10) and electromagnetic waves reflection $(8,11)$. Multifunctionality is obtained by adding different additions to the cementitious matrix composite, such as conductive carbon materials, which can maintain or improve its structural characteristics and can be compatible with a wide variety of cementitious matrix $(12,13)$

Carbon nanofibers (CNF) are one of the additions that can be used to create multifunctional materials. Researching and developing CNF cementitious matrix composites opens a new line to obtain multifunctional materials, possibly more efficient and with a wider range of application fields.

Dispersion is the most challenging issue in the study of carbon nanoparticles composites, including CNF cementbased composites. CNF have unique mechanical, electrical and thermal properties. However, strong van der Waals self-attraction forces that occur among the fibers results in a high tendency to agglomerate in fiber clumps really difficult to disperse, and results in a loss in properties or even a degradation of the original material. The great advances en CNF polymer composites have not been equally achieved in cementitious composites, in part due to this dispersion problem.

Different methods have been used to disperse nanofibers, such us the combined use of surfactants and sonication, the modification of the surface of the nanofibers, functionalizing (incorporating molecular groups to the fiber surface so to improve the affinity with the matrix) (14), and even the direct grown of carbon 
en los granos de cemento no hidratado (15). Sanchez (16) propone una mezcla en seco de cemento, nanofibras de carbono y humo de sílice, para su posterior amasado con agua, concluyendo que el humo de sílice, gracias a su pequeño tamaño de partícula, facilita la dispersión y mejora la interacción interfacial entre las NFC y las fases del cemento. Por el contrario, Yazdanbakhsh (17) pone de manifiesto serios inconvenientes, como por ejemplo, el efecto negativo de muchos surfactantes (adecuados para la dispersión de nanofibras y nanotubos de carbono) en la hidratación del cemento, la rotura y acortamiento de nanofibras de carbono por efecto del sonicado excesivo, o incluso, el empeoramiento de las propiedades de la matriz cementicia al utilizar cementos de grano fino (por molienda de cemento no tratado, de tamaño de grano superior al de las NFC). En este mismo estudio se comprueba, comparando imágenes ópticas de las dispersiones (buena dispersión) con imágenes SEM de la pasta con NFC (mala dispersión), que una buena dispersión de NFC en agua con surfactante no garantiza una correcta distribución de las NFC en la matriz cementicia.

A pesar de las ventajas potenciales de la presencia de las NFC en la matriz cementicia, hay muy pocas referencias en la literatura técnica especializada sobre las propiedades mecánicas de morteros de cemento Portland fabricados con adición de NFC $(18,19)$. Existe gran disparidad entre los resultados publicados: desde incrementos importantes de las resistencias obtenidas (20) (a pesar de una distribución no homogénea de las fibras en la matriz cementicia), hasta estudios en los que no se encontraron variaciones sustanciales (21). Sin duda, el tipo de NFC y el grado de dispersión de estas en la matriz cementicia juegan un papel importante.

Por otro lado, no existen referencias sobre estudios de corrosión de barras de acero embebidas en materiales cementantes con NFC. Es, por lo tanto, un objetivo de este artículo presentar datos sobre la cinética de corrosión del acero de refuerzo embebido en estos morteros frente a fenómenos como la carbonatación y el ingreso de cloruros. Para este propósito se ha estudiado el comportamiento de morteros con adición de NFC, con diferentes composiciones y sometidos a una carbonatación acelerada y a la acción del agua de mar, a fin de caracterizar su durabilidad frente a estos fenómenos.

\section{EXPERIMENTAL}

\subsection{Materiales y preparación de probetas}

Se han preparado pastas y morteros utilizando cemento Portland tipo CEM I 52.5 R de acuerdo con la normativa española (UNE-EN 196-1). La composición química de este nanofibers on unhydrated cement grains (15). Sanchez (16) proposes a dry mixture of cement, carbon nanofiber and silica fume, and its latter mix in water, concluding that the silica fume, due to its small particle size, facilitates dispersion and improves interfacial interaction between the CNFs and the cement phases. On the other hand Yazdanbakhsh (17) states serious difficulties, like the negative effect of many surfactants (adequate for CNF and CNT dispersion) during the cement hydration, the breakage and shortening of CNF by excessive ultrasonic energy, or even the deterioration of the cement-composite properties while using small particle size cements (milling untreated cement, which grain size was bigger than the CNFs). In this research it was also concluded, comparing optical images of dispersions (good dispersion) with SEM images of the CNF cementpaste (bad dispersion), that obtaining good dispersions of CNF in water with surfactants does not guarantee a correct distribution of the CNF en the cement matrix.

Despite the potential advantages of CNF cement based composites, very few studies have been conducted in order to investigate the mechanical properties of Portland cement mortars fabricated with addition of CNF $(18,19)$. There is a wide variety of results concerning mechanical properties: from huge increments (20) (even though the dispersion obtained was inhomogeneous), to no variations (21). Undoubtedly, the type of CNF and its dispersion in the cement matrix play an important role.

Besides, no reference to corrosion of steel rebars embedded in CNF cementitious composites have been found in the scientific literature reviewed. So, one of the objectives of this research is the study of the corrosion kinetics of steel reinforcements embedded in cement mortars in aggressive environments such as carbonation and chlorides. To this purpose, in order to characterize its durability, the behavior of CNF cement mortars with different CNF dosages and subjected to accelerated carbonation and the action of sea water has been investigated.

\section{EXPERIMENTAL}

\subsection{Materials and specimens}

Cement pastes and mortars with CEM I 52.5 R Portland cement type, according to Spanish standard (UNE-EN 196-1), have been fabricated. Its chemical composition 
material se muestra en la Tabla 1. Las pastas se han utilizado para la fabricación de probetas para ensayos de velocidad de corrosión, mientras que los morteros se han empleado en los ensayos mecánicos. Se ha utilizado pasta para este estudio a fin de maximizar la influencia de la matriz cementicia en el proceso de corrosión. En las mezclas se han utilizado siempre arena silícea normalizada (para el caso de los morteros) y agua destilada. Los morteros fueron fabricados siempre con relación agua/cemento $(\mathrm{a} / \mathrm{c}) \mathrm{de}$ 0,5 y cemento/arena de $1 / 3$. Las NFC (GANF4) fueron suministradas por la compañía Grupo Antolín-Irausa, S.A. (España). Se ha utilizado plastificante Sikament FF suministrado por Sika, S.A.U. (España). Los morteros han sido fabricados en ambiente de laboratorio: $20{ }^{\circ} \mathrm{C}$ de temperatura y $80 \%$ de humedad relativa (HR). El tiempo de mezclado en la amasadora ha sido siempre de 5 minutos a fin de obtener siempre una mezcla totalmente homogénea.

Para la dispersión de NFC se adaptado un método previamente usado que ofrece resultados satisfactorios en matrices poliméricas (22). Las NFC se han vertido junto al agua destilada en una mezcladora de aspas planas. Tras este amasado previo la mezcla ha sido sonicada. La dispersión resultante se ha vertido en amasadora estándar junto con el cemento y el plastificante.

Para los ensayos mecánicos se han fabricado probetas prismáticas de $4 \times 4 \times 16 \mathrm{~cm}^{3}$ mediante compactación mecánica en dos capas. Las probetas se han curado bajo agua siendo ensayadas mecánicamente a las siguientes edades de curado: 7, 28 y 120 días. Los ensayos mecánicos se han realizado en condiciones de laboratorio según lo establecido en la norma UNE-EN 196-1. Las proporciones de NFC y plastificante utilizadas en estas pastas son las mostradas en la Tabla 2.

Para los ensayos de velocidad de corrosión de aceros se han fabricado probetas prismáticas de pastas de NFC de dimensiones $80 \times 55 \times 20 \mathrm{~mm}^{3}$, en las cuales se han empleado las proporciones de NFC y plastificante mostradas en la Tabla 2. La relación a/c empleada ha sido de 0,5. Cada probeta contiene dos electrodos cilíndricos de $8 \mathrm{~mm}$ de diámetro de acero al carbono y un contraelectrodo de grafito en el medio. El espesor de recubrimiento resultante es de $6 \mathrm{~mm}$. La Figura 1 muestra un esquema de las probetas utilizadas para las medidas de corrosión, similares a las utilizadas en estudios precedentes (23-27). El área expuesta del acero ha sido de $16,3 \mathrm{~cm}^{2}$. is shown in Table 1. Pastes have been used for corrosion rate tests, while mortars have been used for the mechanical ones. By using pastes, this research tries to maximize the influence of the cement matrix in the corrosion process. Standard Silica sand (mortars) has always been used and distilled water. Mortars were fabricated with a water/cement ratio $(w / c)$ of 0.5 and a cement/sand ratio (c/s) of $1 / 3$. Commercially available GANF-4 CNFs (Grupo Antolín, Inc., Spain), and Sikament FF commercial superplasticizer (SIKA, Inc., Spain) were used. Mortars were fabricated in laboratory conditions: $20^{\circ} \mathrm{C}$ temperature and $80 \%$ relative humidity $(\mathrm{RH})$. The mixing time has always been of 5 minutes so to obtain homogeneous mixtures.

CNFS dispersions have been done by a previously checked method in polymer composites (22). CNFs and distilled water have been poured in a high-shear mixer and then sonicated. The resulting dispersion has been mixed with cement and superplasticizer in a laboratory mixer.

Prismatic specimens of $4 \times 4 \times 16 \mathrm{~cm}^{3}$ have been fabricated according to Spanish Standards for mechanical tests. Specimens have been cured in water and tested at 7, 28 and 120 days curing time. Mechanical tests have been accomplished in laboratory conditions according to European Standard UNE EN 196-1. Dosages of CNFS and superplasticizer used are shown in Table 2.

Prismatic specimens of $80 \times 55 \times 20 \mathrm{~mm}^{3}$ have been fabricated for corrosion rate tests, with dosages of CNFs and superplasticizer shown in Table 2 . The $w / c$ ratio has been 0.5. Each specimen contains two $8 \mathrm{~mm}$ diameter cylindrical electrodes made of steel and a graphite counterelectrode in the middle. The thickness of the resulting cement paste cover was $6 \mathrm{~mm}$. Figure 1 shows the specimens used for corrosion tests, which are similar to others previously studied (23-27). The exposed steel area has been $16.3 \mathrm{~cm}^{2}$.

Tabla 1 / Table 1

Análisis químico del cemento Portland utilizado en el estudio.

Chemical analysis of the Portland cement used in this study.

\begin{tabular}{|c|c|c|c|c|c|c|c|c|c|}
\hline $\mathrm{CaO}$ & $\mathrm{SiO}_{2}$ & $\mathrm{Al}_{2} \mathrm{O}_{3}$ & $\mathbf{M g O}$ & $\mathrm{Fe}_{2} \mathrm{O}_{3}$ & $\mathbf{S O}_{3}{ }^{-}$ & $\mathbf{S}^{2-}$ & $\mathrm{Na}_{2} \mathrm{O}$ & $\mathbf{P F} / \mathbf{L O}^{*}$ & $\mathbf{R I} / \mathbf{I R}^{\star *}$ \\
\hline 61.51 & 19.76 & 3.66 & 2.07 & 4.73 & 3.03 & - & 0.12 & 2.52 & 0.66 \\
\hline
\end{tabular}

* PF: Pérdida al fuego / LOI: Loss on ignition. ** RI: Residuo insoluble / IR: Insoluble residue. 
Tabla 2 / Table 2

Proporciones de NFC y plastificante utilizadas en las probetas de pasta y mortero. CNF dosages and superplasticizer used in cement pastes and mortars.

\begin{tabular}{|c|c|}
\hline $\begin{array}{c}\text { \% NFC / \% CNF } \\
\text { (resp. masa cemento) / (to cement mass) }\end{array}$ & $\begin{array}{c}\text { \% Plastificante / \% Superplasticizer } \\
\text { (resp. masa cemento) / (to cement mass) }\end{array}$ \\
\hline 0.00 & 0.00 \\
\hline 0.25 & 0.29 \\
\hline 0.50 & 0.58 \\
\hline 0.75 & 0.86 \\
\hline 1.00 & 1.14 \\
\hline 1.25 & 1.46 \\
\hline 1.50 & 1.79 \\
\hline 1.75 & 1.95 \\
\hline 2.00 & 2.12 \\
\hline
\end{tabular}

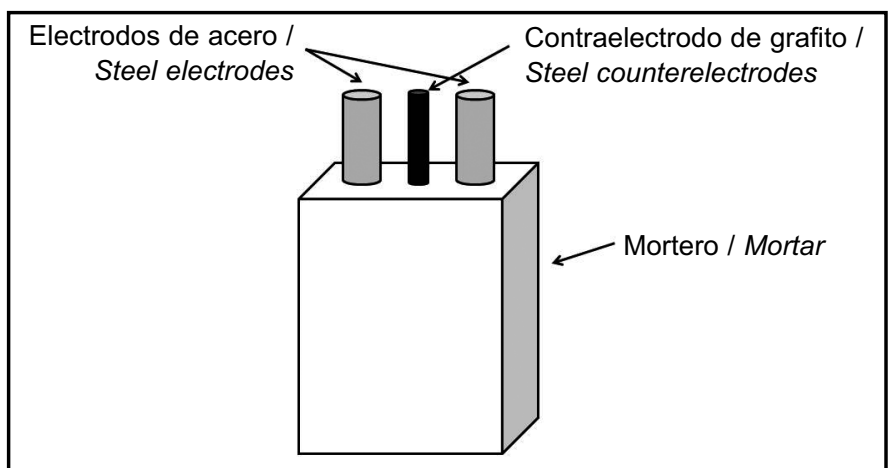

Figura 1. Esquema de las probetas utilizadas para las medidas de corrosión.

Figure 1. Specimens used in corrosion study.

\subsection{Velocidad de paso de ultrasonidos (VPU)}

El equipo empleado en este trabajo para la medida del tiempo de propagación de las ondas sónicas a través de las probetas de mortero ha sido un equipo Ultrasonic Tester BP-5, marca Steinkamp. Para las medidas se utilizaron dos sensores cilíndricos estándar, colocándose las superficies de medida en dos puntos de las probetas longitudinalmente opuestos. En la superficie de los morteros la zona de contacto debe ser lo más lisa y limpia posible. Además, se debe usar vaselina para garantizar un buen contacto. En cada caso, el ensayo se ha realizado antes de que las probetas fueran sometidas a los ensayos de resistencias mecánicas.

La velocidad de paso de ultrasonidos se ha determinado según la ecuación [1].

\subsection{Ultrasonic pulse velocity NDT method (UPV)}

An ultrasonic tester (model Steinkamp BP-5) has been used in order to measure a transit time for the ultrasonic pulse to travel along the cement mortar specimens. Measurements have been done with two standard cylindrical sensors longitudinally placed in opposite sides of the specimens. The mortar contact surface must be as planar and clean as possible. Also vaseline must be used to ensure good contacts. Tests have been made previously to mechanical tests.

UPV has been determined according to equation [1].

$$
V=\frac{e}{t} \times 10^{6}
$$

Donde $V(\mathrm{~m} / \mathrm{s})$ es la velocidad de paso de ultrasonidos (VPU); e (m) es la distancia entre el emisor y el receptor; y $t(\mu \mathrm{s})$ es el tiempo que tarda la onda en atravesar la probeta entre el emisor y el receptor. En este caso $e$ está definido por la longitud de la probeta y su valor es constante e igual a $0,16 \mathrm{~m}$.
Where $V(\mathrm{~m} / \mathrm{s})$ is the ultrasonic pulse velocity (UPV); e $(m)$ is the distance between transducers in contact with the specimen; and $t(\mu s)$ is the time taken by the ultrasonic wave to go through the specimen. In this case $e$ is defined by the specimen length, with a constant value of $0.16 \mathrm{~m}$. 


\subsection{Porosidad}

Se tomaron muestras de los morteros preparados y se analizaron mediante un equipo Autopore IV 9500 V1.05 de la empresa Micromeritics Instrument Corporation. Las muestras se tomaron de los morteros a los 28 días de curado. Se analizaron tres replicados de cada mortero de un volumen aproximado de $1 \mathrm{~cm}^{3}$. Los análisis se realizaron en el intervalo de presiones desde 0,5 a 30 psia ( 3 a $207 \mathrm{kPa}$ ), lo que proporciona datos de poros de entre 360 y $6 \mu \mathrm{m}$ (baja presión) y en el intervalo desde 30 psia a 33.000 psia $(228 \mathrm{MPa})$, proporcionando información sobre poros entre $6 \mu \mathrm{m}$ y $5 \mathrm{~nm}$ (alta presión).

\subsection{Ensayos de corrosión}

En cada probeta se ha medido el valor de velocidad de corrosión (Icorr) y potencial de corrosión (Ecorr) para cada electrodo de acero y se ha tomado como resultado el valor medio de ambos electrodos para cada uno de los parámetros. La duración del proceso de medida ha sido el tiempo suficiente hasta conseguir valores de Icorr estables.

Una vez curadas las probetas durante 32 días en cámara húmeda al $100 \%$ de $\mathrm{HR}$ y $20^{\circ} \mathrm{C}$, un juego de las mismas se ha sometido a inmersión parcial en disolución de $\mathrm{NaCl} 0,5 \mathrm{M}$ que simula el agua de mar. Todos estos ensayos se han realizado a una temperatura de $20^{\circ} \mathrm{C}$. Las probetas están parcialmente cubiertas por el agua, dejándose en su parte superior $1 \mathrm{~cm}$ de las mismas sin sumergir, para evitar el contacto directo de los electrodos con los cloruros, según se muestra en la Figura 2. El otro juego de probetas se ha sometido a un proceso de carbonatación acelerada en una atmósfera del $100 \%$ de $\mathrm{CO}_{2}$ y una humedad relativa del $65 \pm 5 \%$.

La técnica electroquímica usada para medir la velocidad de corrosión instantánea, Icorr, ha sido la técnica de la resistencia de polarización $(R p)$; utilizando la ecuación de Geary y Stern (28) que relaciona ambos parámetros, mostrada en la ecuación [2].

\subsection{Porosity}

Mortar samples have been taken and analyzed with an Autopore IV 9500 V1.05 equipment (Micromeritics Instrument, Inc.), at 28 days of curing time. Three replicates with an approximate volume of $1 \mathrm{~cm}^{3}$ have been tested. Tests have been made in the pressure range from 0.5 to 30 psia (3 to $207 \mathrm{kPa}$ ), which gives information about porous between 360 and $6 \mu \mathrm{m}$ (low pressure), and the pressure range from 30 to 33000 psia (207 $\mathrm{kPa}$ to $228 \mathrm{MPa}$ ), giving information about porous between $6 \mu \mathrm{m}$ and $5 \mathrm{~nm}$ (high pressure).

\subsection{Corrosion tests}

Corrosion velocity (Icorr) and corrosion potential (Ecorr) have been tested to each steel electrode, taken the mean value of the two electrodes of each specimen to each parameter. Each process has lasted time enough to obtain stable Icorr values.

After 32 days of curing in wet chamber (100\% RH and $20{ }^{\circ} \mathrm{C}$ ), one series of each specimen type have been immersed in a $0.5 \mathrm{M} \mathrm{NaCl}$ solution, simulating sea water. All these tests have been done at $20^{\circ} \mathrm{C}$ temperature. The specimens have been partially immersed in the solution, leaving $1 \mathrm{~cm}$ unimmersed to avoid direct contact of the electrodes with the solution, as shown in Figure 2. The other series has been exposed to an accelerated carbonation process in $100 \% \mathrm{CO}_{2}$ atmosphere and $65 \pm 5 \% \mathrm{RH}$.

Polarization resistance technique $(R p)$ has been used for testing instant corrosion rate (Icorr) by using Geary and Stern equation (28), as shown in equation. [2].

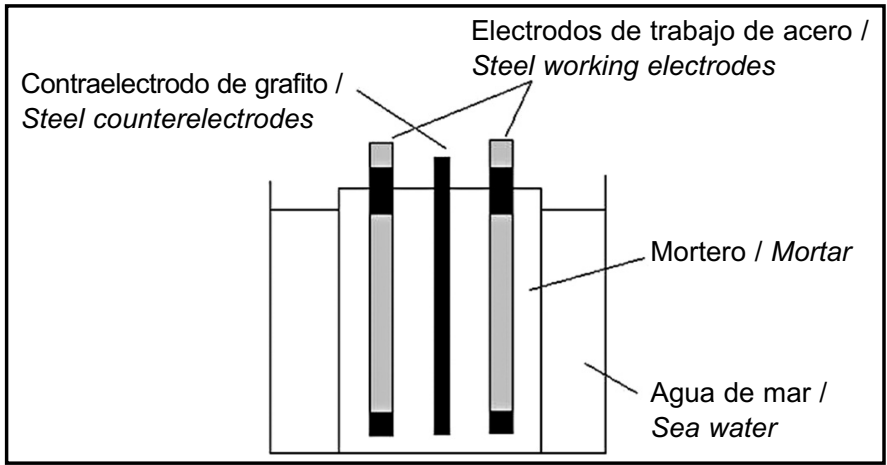

Figura 2. Esquema de la probeta sometida al proceso de ataque por agua de mar. Figure 2. Specimen partially immersed in sea water. 
Donde Icorr es la velocidad de corrosión $\left(\mu \mathrm{A} / \mathrm{cm}^{2}\right) ;$ Rp es la resistencia de polarización $\left(\mathrm{k} \Omega \cdot \mathrm{cm}^{2}\right)$ y $B(\mathrm{mV})$ es una constante cuyo valor se asume igual a $26 \mathrm{mV}$ para el sistema acero-cemento (29). Durante todo el tiempo del experimento se ha medido periódicamente el valor de Icorr y Ecorr. Al final del mismo, se ha determinado para cada electrodo la pérdida de peso gravimétrica. Todos los valores de potencial están referidos al electrodo de calomelanos saturado (SCE). Se ha usado un potenciostato 362 EG\&G distribuido por Princeton Applied Research. Los valores de Icorr han sido calculados como el valor medio entre cuatro medidas (dos probetas, dos electrodos cada una). La pérdida electroquímica estimada de la integración de las curvas de Icorr en función del tiempo ha sido comparada con la pérdida gravimétrica correspondiente (obtenida directamente mediante pesada). La buena concordancia obtenida entre ambas valida el valor de $B$ empleado.

\section{RESULTADOS Y DISCUSIÓN}

\subsection{Ensayos de propiedades mecánicas}

La Figura 3 muestra la influencia del porcentaje de adición de NFC en la resistencia a compresión y la velocidad de paso de ultrasonidos para morteros de cemento Portland curados bajo agua a $20{ }^{\circ} \mathrm{C}$, y siendo las edades de curado de 7, 28 y 120 días. La adición NFC a los composites de matriz cementicia tiene por tanto un efecto favorable sobre la resistencia a compresión de los morteros. La resistencia máxima se da para un contenido de $2 \%$ de NF. En la Figura 4 se presenta la relación que se puede establecer entre el incremento de la resistencia a compresión y el porcentaje de adición de NFC. La ecuación [3]
Where Icorr is the corrosion rate $\left(\mu A / \mathrm{cm}^{2}\right) ; R p$ is the polarization resistance $\left(\mathrm{k} \Omega \cdot \mathrm{cm}^{2}\right)$ and $B(\mathrm{mV})$ is a constant which value is assumed equal to $26 \mathrm{mV}$ for the steel-cement system (29). Icorr and Ecorr have been periodically measured. At the end of this experimental, gravimetric weight loss has been determined. All the potential values are referred to the saturated calomel electrode (SCE). In order to determine the polarization resistance a 362 EG\&G potentiostat (Princeton Applied Research) has been used. Icorr values have been calculated as the mean value of four measurements (two specimens, two electrodes each). The electrochemical loss estimated by integrating Icorr curves as a function of time has been compared to the correspondent gravimetric loss (obtained directly by its weight). The agreement between both results validates de $B$ value.

\section{RESULTS AND DISCUSSION}

\subsection{Mechanical properties tests}

Figure 3 shows the influence of the quantity of CNF addition in the compressive strength and in the ultrasonic pulse velocity, for Portland cement mortars cured at $20{ }^{\circ} \mathrm{C}$, tested at curing ages of 7, 28 and 120 days. The addition of CNF to cement based composites increases the compressive strength of the mortars. The maximum strength is obtained for a $2 \%$ CNF content. Figure 4 shows the correlation between compressive strength and CNF dosages. Equation [3] shows this correlation as a lineal fitting where $\Delta R C$ and $C N F$ are expressed in percentages. According to this correlation,

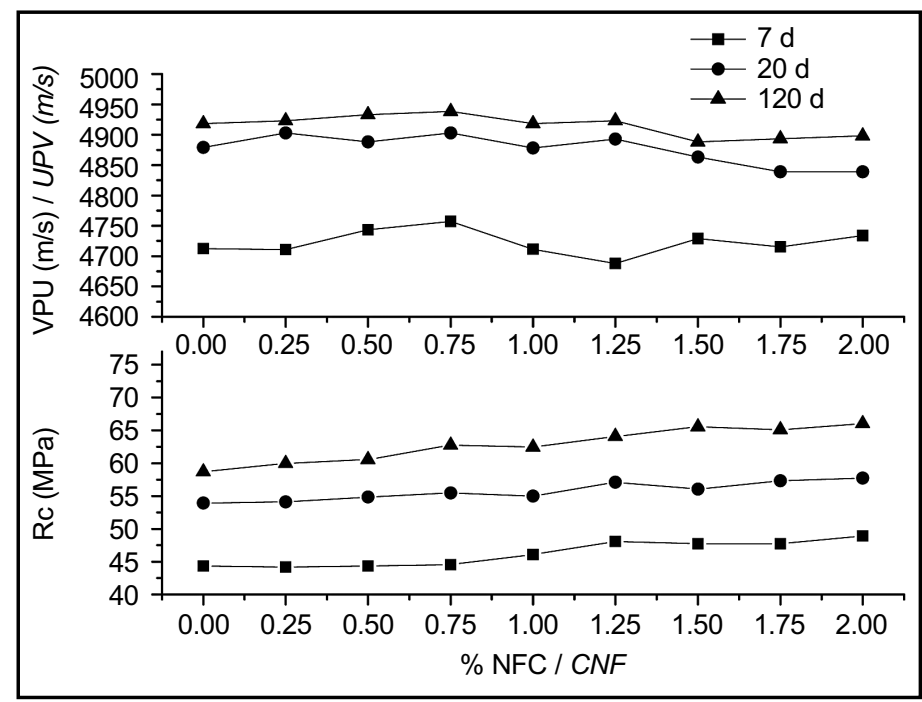

Figura 3. Resistencia a compresión (Rc) y la velocidad de paso de ultrasonidos (VPU) en función del porcentaje de NFC para morteros de cemento Portland a distintas edades de curado.

Figure 3. Effect of the CNF dosages on the compressive strength $(R c)$ and the ultrasonic pulse velocity (UPV), in Portland cement mortars at different curing times. 
relaciona ambos parámetros según un ajuste lineal en la cual $\Delta R c$ y NFC se expresan como porcentajes. En base a esto se puede apreciar que se produce un incremento de un $5,3 \%$ de la resistencia a compresión por cada $1 \%$ de NFC que se adiciona al mortero. it can be established that an increase of $5.3 \%$ of the compressive strength can be achieved for every $1 \%$ of CNF added to the mortar.

$$
\Delta \mathrm{Rc}(\%)=-0.4+5.27 \times \mathrm{CNF}(\%)
$$

Por otra parte, la velocidad de paso de ultrasonidos a través de la pasta cementicia dependerá de la composición mineralógica, de las conexiones intercristalinas, del contenido de humedad y fundamentalmente del volumen de poros en el mortero. La no dependencia que se observa entre los datos de VPU y el porcentaje de $\mathrm{NFC}$, indicaría que el aumento de resistencia a compresión tendría origen en un refuerzo de las NFC y no por un mecanismo de densificación del material. No obstante, al aumentar la edad de curado se puede apreciar que tanto la resistencia compresión como la VPU aumentan, dado que en este caso, la ganancia de resistencia que es debida a la edad, sí que tiene como causa una mayor densidad del material, la cual es consecuencia de la evolución de la hidratación del cemento. En la Figura 5 se muestra la relación entre ambos parámetros, cuyos datos de ajuste lineal se muestran en la ecuación [5], donde $R c$ es la resistencia a compresión en MPa y VPU es la velocidad de paso de ultrasonidos en $\mathrm{m} / \mathrm{s}$. En dicha figura, se comprueba como los puntos se agrupan en función de la edad de curado y no a causa del porcentaje de adición de NFC, por lo que este tipo de relaciones como la que se muestra en la ecuación [4] tiene únicamente sentido cuando el mecanismo de ganancia de resistencia se debe a una reducción de la porosidad.
Besides, the UPV going through the cement matrix depends on the mineralogical composition, the intercrystalline connections, the humidity content and basically the porous volume in the mortar. The low influence of the CNF content in the UPV could indicate that the increase in the compressive strength would have its origin in a reinforcement of the CNF rather than in an increase in the composite density. Nevertheless, an increase in the curing time implies higher compressive strength and higher UPV, in this case due to the increase in density caused by the cement hydration evolution. Figure 5 shows the relation between both parameters, which lineal adjustment is shown in equation [4], where $R C$ is the compressive strength in MPa and UPV is the ultrasonic pulse velocity in $\mathrm{m} / \mathrm{s}$. In this figure, data is gathered as a function of curing time but not according to the CNF addition dosage, and that is the reason why this kind of relation shown in equation [4] only is applicable when the increase in strength is due to a reduction in porosity.

$$
\mathrm{Rc}=0.073-294.70 \times \mathrm{VPU}
$$

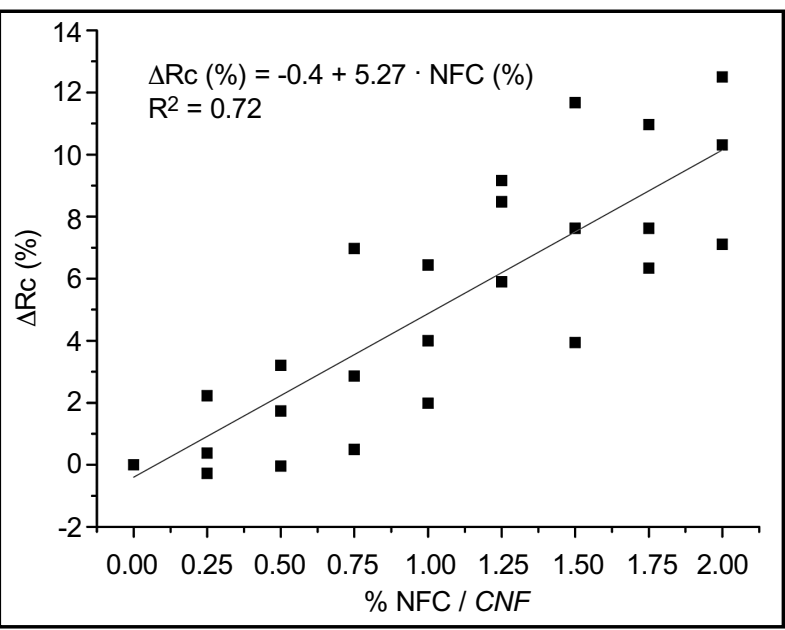

Figura 4. Relación entre el incremento de resistencia a compresión y el porcentaje de adición de NFC en morteros de cemento. Figure 4. Relation between the increase in compressive strength and the CNF dosages, in cement mortars.

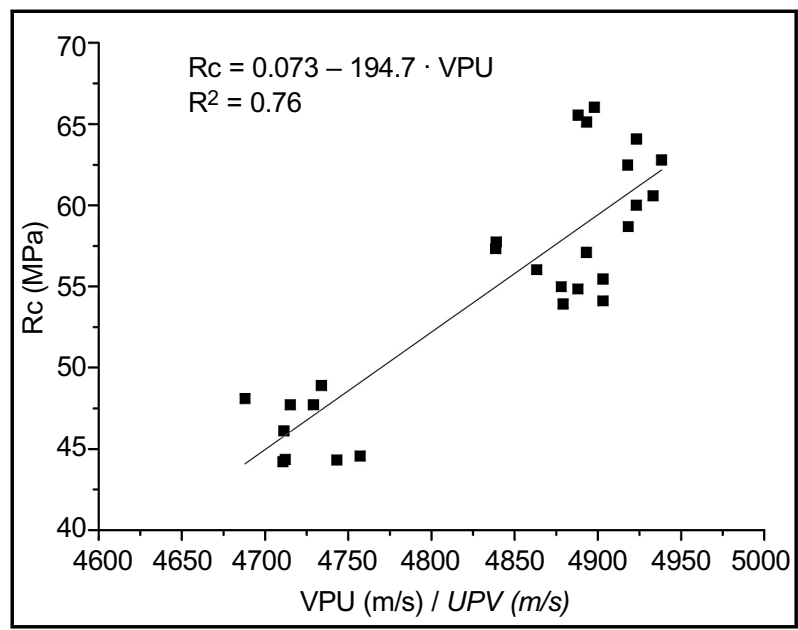

Figura 5. Relación entre la resistencia a compresión (Rc) y la velocidad de paso de ultrasonidos (VPU) en los morteros con NFC.

Figure 5. Relation between compressive strength $(R c)$ and ultrasonic pulse velocity (UPV), in CNF cement mortars. 
La Figura 6 muestra la relación entre la densidad y la porosidad en función del porcentaje de NFC para morteros de cemento Portland curados bajo agua a $20^{\circ} \mathrm{C}$, y siendo la edad de curado de 28 días. En dicha figura se muestra que ni la densidad ni la porosidad varían sensiblemente con el contenido de NFC. Este hecho apoyaría la hipótesis de que el aumento que se observa en la resistencia a compresión de los morteros según aumenta la cantidad de NFC, se deba a cierto refuerzo que puedan producir en la matriz cementicia, ya que no se ha modificado la densidad del mortero. Además, una modificación en la densidad también habría producido un cambio en la velocidad de paso de ultrasonidos, cosa que no se observa, según se aprecia en la Figura 3.
Figure 6 shows the relation between density and porosity for each CNF dosage, in Portland cement mortars cured in water at $20^{\circ} \mathrm{C}$, at 28 days of curing time. In this figure neither density nor porosity significantly varies with the content of CNF. As no major modification in density is observed, the hypothesis of CNF as reinforcement for the cement matrix could be consistent. Moreover, a density variation will also have produced a change in UPV, which has not been observed, according to Figure 3.

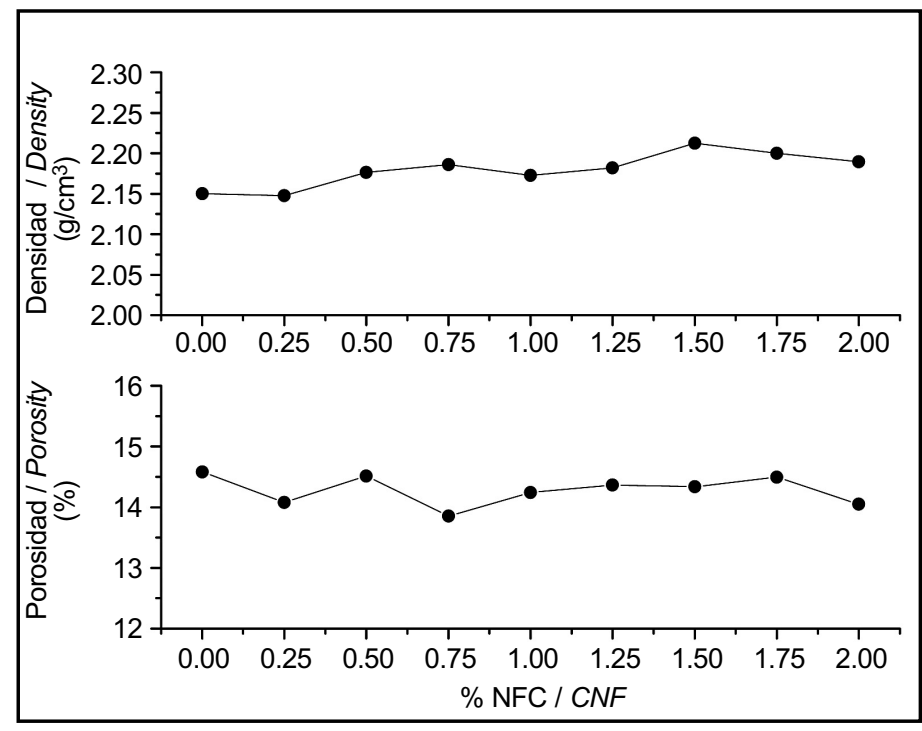

Figura 6. Densidad y porosidad en función del porcentaje de NFC para morteros de cemento Pórtland.

Figure 6. Effect of the CNF dosages on the density and the porosity of Portland cement mortars.

La Figura 7 muestra el valor registrado de la resistencia a flexotracción (Rf) en función del porcentaje de NFC para morteros de cemento Portland curados bajo agua a $20{ }^{\circ} \mathrm{C}$, y siendo las edades de curado de 7, 28 y 120 días. En primer lugar se observa, en mayor o menor grado, que el aumento del tiempo de curado implica un aumento del valor de resistencia a flexotracción de las probetas. Siendo este incremento más significativo en el caso de la probeta control sin NFC. Por otra parte, se observa que el aumento en la cantidad de NFC no influye de forma significativa en el valor de resistencia a flexotracción.

La Figura 8 muestra el volumen incremental de intrusión de mercurio frente al tamaño de poro para distintos porcentajes de NFC en morteros de cemento Portland curados bajo agua a $20^{\circ} \mathrm{C}$, a 28 días de edad de curado. La superposición de líneas indica pequeñas variaciones de distribución de tamaños de poros. No obstante, el patrón ( $0 \%$ NFC) se encuentra siempre por encima del resto, lo que indica una disminución de la porosidad para todos
Figure 7 shows the flexural strength for each CNF dosage, in CNF Portland cement mortars water cured at $20{ }^{\circ} \mathrm{C}$, at 7, 28 and 120 days of curing time. It can be first observed that the specimen flexural strength increases with curing time. The higher increase is obtained for the control specimen, with no CNF. On the other side, the increase in CNF dosage does not significantly affects the flexural strength.

Figure 8 shows the incremental volume of $\mathrm{Hg}$ intrusion versus the pore size, for each CNF dosages in Portland cement mortars, cured in water at $20^{\circ} \mathrm{C}$, at 28 days of curing time. The lines overlap implies non-significant variations of pore size distribution. Nevertheless, control mortar (0\% CNF) is always above the rest, indicating less porosity of all the analyzed CNF mortars than the control. On the other side, little variation 
los morteros analizados con NFC frente a aquel. Por otro lado, las variaciones de porosidad entre los distintos morteros que sí contienen NFC es pequeña.

Lo anterior queda más claramente reflejado en la Figura 9, que muestra la distribución de tamaños de poro de morteros con adición de diferentes porcentajes de NFC, a 28 días de curado. Se comprueba que únicamente hay variaciones significativas en los intervalos $10 \mathrm{~nm}-100 \mathrm{~nm}$ y $100 \mathrm{~nm}-1 \mu \mathrm{m}$. En el primer caso aumentando con el incremento de adición de NFC y en el segundo caso disminuyendo. Las pequeñas variaciones de porosidad comentadas corresponden por tanto a un aumento de poros de entre 10 y $100 \mathrm{~nm}$ y una disminución entre $100 \mathrm{~nm}$ y $1 \mu \mathrm{m}$, siendo el balance global equilibrado, con ligera tendencia a la disminución de la porosidad total con el aumento de NFC.

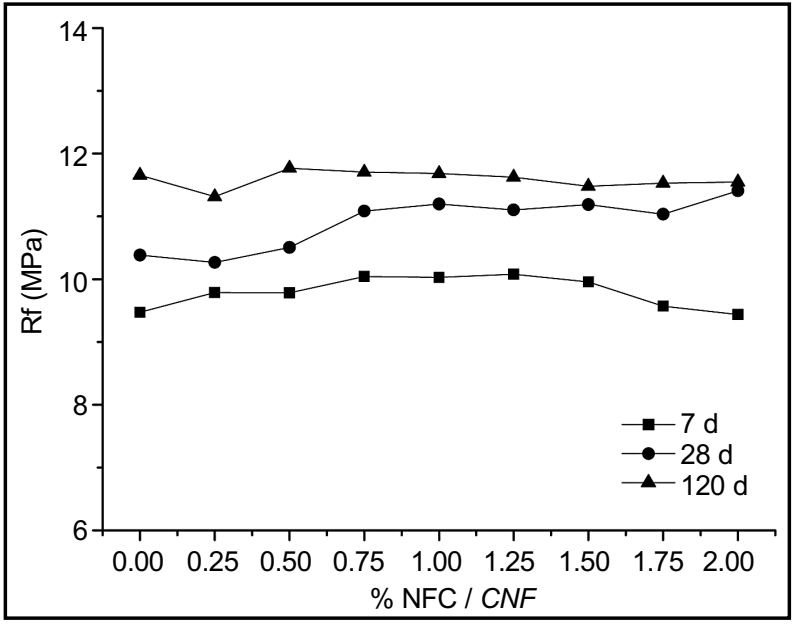

Figura 7. Resistencia a flexotracción (Rf) en función del porcentaje de NFC para morteros de cemento Portland y distintas edades de curado.

Figure 7. Effect of the CNF dosages on the flexural strength (Rf), in Portland cement mortars at different curing times. among the mortars with addition of CNF has been found.

The former is more clearly shown in Figure 9, which depicts the pore size distribution of mortars with different dosages of CNF, at 28 days of curing time. Significant variations can only be found at $10 \mathrm{~nm}-100 \mathrm{~nm}$ (increasing with the increment of CNF addition) and 100 $n m-1 \mu m$ (diminishing with the increment of CNF addition). The small porosity variations previously observed are due to an increase in the porous volume between 10 and $100 \mathrm{~nm}$, and a decrease in the porous volume between $100 \mathrm{~nm}$ and $1 \mu \mathrm{m}$. Thus, the global effect is an equally balanced total volume of pores, with a slight tendency of the total porosity to decrease as the CNF content is increased.

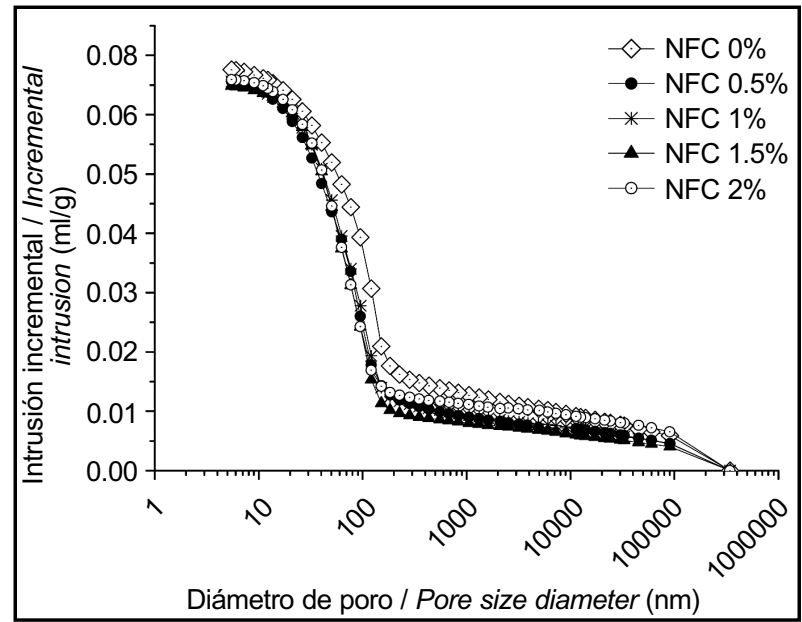

Figura 8. Intrusión incremental de $\mathrm{Hg}$ en función del tamaño de poro, para distintos porcentajes de NFC en morteros de cemento Portland, a 28 días de curado.

Figure 8. Accumulated pore size distribution for the different CNF dosages in Portland cement mortars, at 28 days curing time.

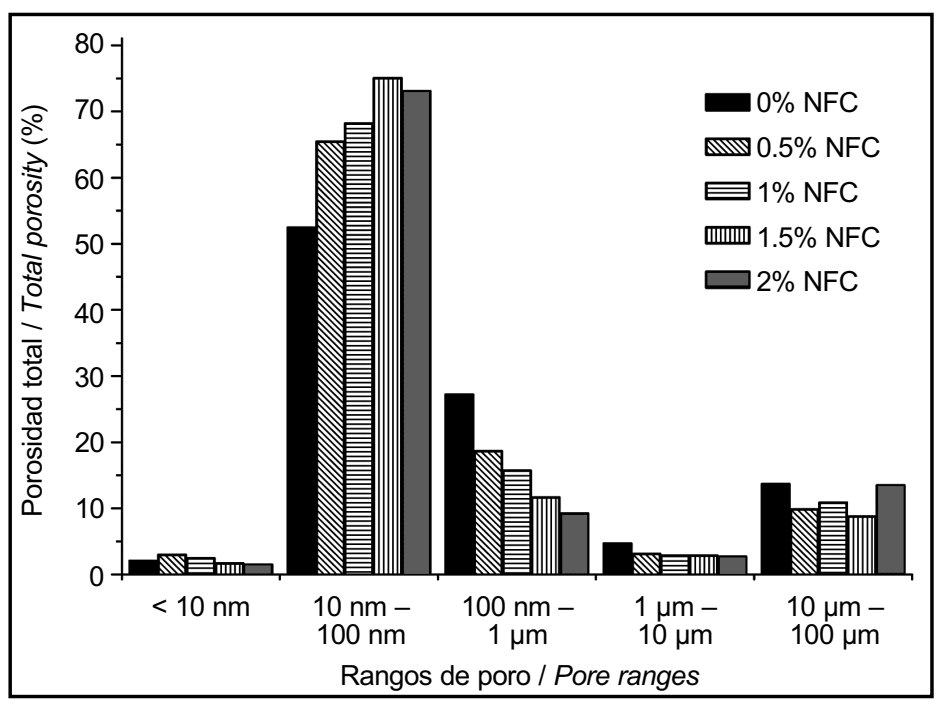

Figura 9. Distribución de tamaños de poro para morteros con adición de diferentes porcentajes de NFC, a 28 días de curado (según rangos de poro).

Figure 9. Pore size distribution (pore ranges) in cement mortars with different CNF dosages, at 28 days curing time. 
Los resultados obtenidos en las porosimetrías son consistentes con los datos de resistencias mecánicas obtenidos.

\subsection{Medidas de corrosión en barras de refuerzo embebidas en NFC}

Habitualmente, en las estructuras de hormigón armado, las armaduras se encuentran en estado pasivo a causa del elevado pH del hormigón. Sin embargo, pueden presentarse circunstancias en las que se destruye la pasividad del acero, corroyéndose las armaduras a causa de determinados factores desencadenantes del proceso de corrosión, esencialmente la carbonatación del hormigón y/o la presencia de cloruros por encima de un umbral de concentración crítico. La transición del estado pasivo al activo sucede y, como consecuencia de ello, el periodo de vida útil del elemento estructural se reduce rápidamente.

El objetivo de esta parte del estudio realizado es la caracterización del nivel de corrosión que presenta la armadura embebida en pastas de cemento con adición de diferentes porcentajes de NFC. Para el desarrollo de este estudio, las probetas han sido sometidas a diferentes condiciones de ataque. Por un lado, se han sometido las probetas a un proceso de carbonatación acelerada. Y por último se ha estudiado la acción despasivante de los iones cloruro introduciendo parcialmente las probetas en una disolución que simula el agua de mar.

En la Figura 10 se presenta la evolución del potencial de corrosión (Ecorr) y la velocidad de corrosión (Icorr) de aceros embebidos en pastas de cemento con NFC sometidas a un proceso de carbonatación acelerada mediante exposición continuada a una atmósfera de $\mathrm{CO}_{2}$. Las pastas de recubrimiento se diferencian entre sí en el porcentaje
The results by porosimetry are consistent with the mechanical strengths obtained.

\subsection{Corrosion measurements of embedded reinforced rebars in CNF cement pastes}

Usually, reinforced concrete rebars are passivated due to the high $\mathrm{pH}$ level provided by the cement hydration products. Nevertheless, some circumstances can destroy passive film on the steel surface. The main processes leading to the destruction of the passive film are the carbonation of concrete cover and/or the presence of chlorides over the critical concentration threshold. The transition from passive to active state occurs, and as a consequence, the structural element service life rapidly decreases.

The aim of this study is the characterization of the corrosion rate observed in embedded rebars in cement pastes with addition of different dosages of CNF. The specimens have been exposed to different aggressive environments. One of these aggressive environments has been accelerated carbonation. On the other hand, the chloride ion depassivating action has been studied by partial immersion of the specimens in a solution simulating sea water.

Figure 10 presents the evolution of corrosion potential (Ecorr) and corrosion rate (Icorr) of steel rebars embedded in CNF cement pastes, exposed to accelerated carbonation. The cement pastes have different contents of CNF related to the cement mass: $0 \%, 0.25 \%, 0.75 \%, 1.25 \%$ and $1.75 \%$. In Figure 10 a

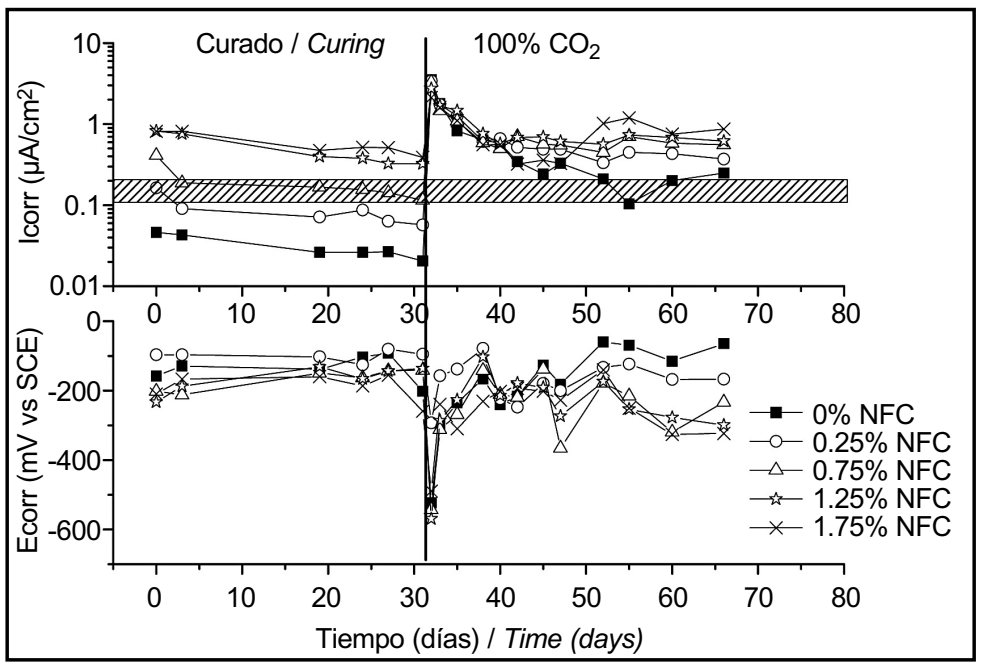

Figura 10. Evolución del potencial de corrosión (Ecorr) y la velocidad de corrosión (Icorr) de aceros embebidos en pastas de cemento con NFC sometidas a un proceso de carbonatación acelerada mediante exposición continuada a una atmósfera de $\mathrm{CO}_{2}$.

Figure 10. Evolution of corrosion potential (Ecorr) and corrosion rate (Icorr) of steel rebars embedded in CNF cement pastes, in accelerated carbonation environment, by continuous exposition to $\mathrm{CO}_{2}$ atmosphere. 
de adición de NFC en relación al peso de cemento. Los porcentajes empleados fueron de $0 \%, 0,25 \%, 0,75 \%, 1,25 \%$ y $1,75 \%$. En la Figura 18 se ha incluido una banda que comprende el intervalo de velocidad de corrosión entre 0,1 y $0,2 \mu \mathrm{A} / \mathrm{cm}^{2}$. Esta banda señala el umbral que separa una corrosión activa (por encima de $0,2 \mu \mathrm{A} / \mathrm{cm}^{2}$ ) de una corrosión despreciable (por debajo de $0,1 \mu \mathrm{A} / \mathrm{cm}^{2}$ ) (29). Durante el periodo de curado, la tendencia habitual es a que la velocidad de corrosión del acero se vaya reduciendo a medida que se consigue pasivar el acero hasta situarse por debajo del umbral de corrosión. En este caso se puede apreciar que para porcentajes de NFC mayores del $1 \%$ los aceros embebidos no han conseguido pasivarse satisfactoriamente en un breve periodo de tiempo. Por otra parte, en el momento de iniciar el proceso de carbonatación, se observa un acusado aumento de la velocidad de corrosión. Dicho fenómeno se debe a la despasivación de la superficie del acero a consecuencia del descenso del pH producido por la carbonatación del recubrimiento. Este aumento de la velocidad de corrosión está acompañado por un marcado descenso del potencial de corrosión. A pesar de que tras el inicio de la carbonatación no se observan diferencias en la velocidad de corrosión ofrecida por los aceros de las distintas pastas de cemento, hacia el final del periodo de ensayo se puede apreciar que a mayor porcentaje de NFC, mayor es la velocidad de corrosión obtenida.

En la Figura 11 se presenta la evolución de los potenciales (Ecorr) y la velocidad de corrosión (Icorr) de aceros embebidos en pastas de cemento con NFC sumergidos parcialmente en agua de mar. Los porcentajes de NFC en los recubrimientos de pasta han sido: $0 \%, 0,5 \%, 1 \%$, $1,5 \%$ y $2 \%$. En la primera etapa, en la que las probetas se mantuvieron en la cámara húmeda, se trataba de desarrollar adecuadamente la matriz cementante antes de someterla al ataque por cloruros. Igual que en el caso corrosion rate band between 0.1 and $0.2 \mu \mathrm{A} / \mathrm{cm}^{2}$ has been included. This band shows the threshold between active corrosion (above $0.2 \mu \mathrm{A} / \mathrm{cm}^{2}$ ) and inactive corrosion (below $0.1 \mu \mathrm{A} / \mathrm{cm}^{2}$ ) (29). During the curing period, the usual tendency of steel corrosion rate is to decrease as the passivated layer is formed, reaching values below the corrosion threshold. However, results show that embedded rebars in CNF pastes with dosages above $1 \%$ have not reached the passivation state in a short period of time. On the other hand, a high increase in the corrosion rate has been observed as soon as the carbonation process starts. This phenomenon is due to the depassivation of the steel surface as the $\mathrm{pH}$ decreases, caused by the carbonation of the cement paste cover. The corrosion rate increase implies a decrease in the corrosion potential. Once the cement paste cover has been carbonated, no differences in corrosion rate have been observed, the increase in CNF dosages implies higher corrosion rates at the end of the carbonation process.

Figure 11 shows the corrosion potential evolution (Ecorr) and the corrosion rate (Icorr) of steel rebars embedded in CNF cement pastes, partially immersed in sea water. The CNF quantities added to the cement pastes have been $0 \%, 0.5 \%, 1 \%, 1.5 \%$ and $2 \%$. In a first stage the specimens have been kept in the humid chamber to obtain an adequate development of the cement matrix, before chloride attack. As in the previous results, no correct passivation state has been found for those

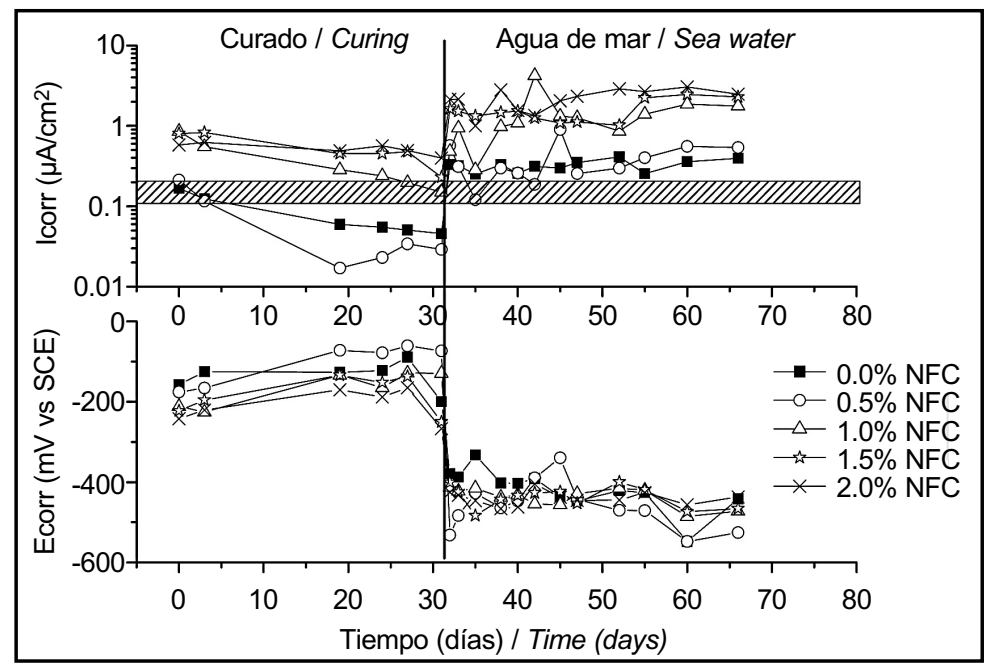

Figura 11. Evolución del potencial de corrosión (Ecorr) y la velocidad de corrosión (Icorr) de aceros embebidos en pastas de cemento con NFC sometidas a un ataque por agua de mar.

Figure 11. Evolution of corrosion potential (Ecorr) and corrosion rate (Icorr) of steel rebars embedded in CNF cement pastes, partially immersed in sea water. 
anterior, se aprecia que los aceros embebidos en las pastas con un contenido en NFC superior al $1 \%$ no se ha pasivado correctamente durante los 30 días que estuvieron curándose la probetas. Tras el curado, las probetas se sumergieron parcialmente en la disolución de $\mathrm{NaCl} 0,5 \mathrm{M}$ que simula la concentración de cloruros que se encuentra en el agua de mar. En este momento se puede apreciar cómo los potenciales de corrosión presentan un desplazamiento hacia valores más negativos, así como un aumento de la Icorr registradas en cada caso. En este caso, todos los valores de velocidad de corrosión de los aceros se sitúan por encima del umbral de corrosión. No obstante, se puede observar que a mayor contenido en NFC, mayor velocidad de corrosión de los aceros embebidos.

Habría que considerar dos aspectos distintos a la hora de discutir y explicar el diferente comportamiento que han mostrados los aceros embebidos en las pastas de cemento con diferentes porcentajes de los materiales carbonosos estudiados. Por una parte la adición de NFC, material conductor, en cantidades crecientes, implica un descenso progresivo de la resistividad del hormigón. Este hecho contribuye al desarrollo de la pila de corrosión, es decir a un aumento de los valores de Icorr registrados. Por otra parte, hay que considerar el par galvánico que se establece entre el acero y los materiales carbonosos conductores. La unión de dos elementos conductores con un diferente nivel de nobleza, de tendencia a oxidarse, implica que el elemento menos noble desarrolle unos niveles de corrosión superiores a los que registraría en ese mismo ambiente estando aislado. Como contrapartida, el elemento más noble desarrollará unos niveles de corrosión más bajos. Esto último es lógico, puesto que los electrones procedentes de la oxidación del elemento menos noble (el acero) ejercerán una protección catódica sobre el elemento más noble (las NFC) al llegar a su superficie. Por lo tanto, un incremento en el porcentaje de material carbonoso añadido contribuye a un aumento de los niveles de Icorr registrados.

En conclusión, de la contribución de estos dos factores cabe esperarse que, cuanto mayor es el porcentaje de NFC añadido a la probeta de mortero, mayor es el nivel de conductividad en la misma y mayor será el efecto de par galvánico que el material carbonoso ejercerá sobre el acero de refuerzo. En consecuencia, por una acción complementaria de estos dos factores, el nivel de corrosión aumenta, lo cual explicaría los resultados obtenidos.

\section{CONCLUSIONES}

En el presente trabajo se han estudiado dos aspectos de la influencia de la incorporación de diferentes cantidades de NFC en matrices cementicias. Por un lado, se ha estudiado el impacto en algunas propiedades mecánicas en specimens with a CNF higher than $1 \%$, after 30 days of curing time. After the curing period, the specimens have been partially immersed in a $0.5 \mathrm{M} \mathrm{NaCl}$ solution simulating sea water chloride concentration. Then, corrosion potentials move to more negative values, and an increase in Icorr values has been observed. In this case, all corrosion rate values are above the corrosion threshold. However, the corrosion rates increase as the CNF content increases.

Two different aspects should be considered to explain the different behavior shown by the steel rebars embedded in cement pastes with different CNF contents. On one hand, the increase in CNF addition, which is an electrical conductive material, implies a progressive decrease in the concrete electrical resistivity. This fact contributes to the development of the corrosion cell, which would mean an increase in the Icorr values. On the other hand, the galvanic couple between the steel and the conductive carbon material must be taken into account. The union of two different conductive materials with different nobility, implies that the less noble tends to develop higher corrosion rates than the same element without the electrical contact with the other one. On the other side, the material with higher nobility develops lower corrosion rates. The former is consistent because the electrons of the less noble material (steel) will cause cathodic protection on the other one (CNF). For this reason, a higher content of CNF implies higher levels of the Icorr values.

As a conclusion of these two factors, it can be expected that the higher CNF content added to the mortar specimen, the higher conductivity and the higher galvanic couple effect from the carbon material to the steel reinforcement are. As a consequence, the complementary action of these two factors implies higher corrosion levels, which is consistent with the results obtained.

\section{CONCLUSIONS}

In the present research the influence of adding CNF to cement composites has been studied in two different variants. On one hand, some mechanical properties of CNF cement mortars, and on the other hand, corrosion 
morteros y, por otro, la influencia en la velocidad de corrosión de aceros embebidos en pastas de cemento con NFC. Las conclusiones que se pueden obtener del presente estudio se resumen en los siguientes puntos:

1. El empleo de NFC como adición en morteros de cemento Portland aumenta los valores de resistencia a compresión de dichos morteros y no afecta significativamente a la resistencia a flexotracción.

2. Esta mejora en las propiedades mecánicas puede venir ocasionada por el refuerzo que produciría la NFC en la matriz cementicia ya que no se observa influencia del porcentaje de adición de NFC sobre la densidad y porosidad del mortero.

3. La adición de NFC a la matriz cementicia puede implicar un aumento del nivel de desarrollo de la pila de corrosión en condiciones agresivas, como la carbonatación del recubrimiento y el ingreso de iones cloruro.

\section{AGRADECIMIENTOS}

Los autores agradecen la financiación concedida a través del siguiente proyecto para la realización de este trabajo: Ministerio de Ciencia e Innovación (Ref.: Mat2009-10866). rates of steel rebars embedded in CNF cement pastes, have been studied. The main conclusions of this research are:

1. The addition of CNF to Portland cement mortars increase the compressive strength and does not significantly affect the flexural strength.

2. This improvement in the mechanical properties could be caused by the CNFs, as reinforcement effect to the cement matrix, because no influence in density or porosity has been observed by the addition of CNF to the cement mortars.

3. The addition of CNF to the cement matrix could imply the development of higher levels of corrosion in aggressive environments, such as carbonation and contamination by chloride ions.

\section{ACKNOWLEDGEMENTS}

The authors would like to thank the financial support given to this research by the Spanish Ministerio de Ciencia e Innovación (Ref.: Mat2009-10866).

\section{BIBLIOGRAFÍA / BIBLIOGRAPHY}

(1) Chen, P. W.; Chung, D. D. L.: "Carbon fiber reinforced concrete as a smart material capable of non-destructive flaw detection", Smart Materials and Structures, 2: 1 (1993), pp. 22-30.

(2) Chen, P. W; Chung, D. D. L.: "Concrete as a new strain/stress sensor", Composites Part B-Engineering, $27 \mathrm{~B}: 1$ (1996), pp. 11-23.

(3) Chen P. W.; Chung, D. D. L.: "Improving the Electrical Conductivity of Composites Comprised of Short Conducting Fibers in a NonConducting Matrix: the Addition of a Non-Conducting Particulate Filler", Journal of Electronic Materials, 24: 1 (1995), pp. 47-51.

(4) Chung, D. D. L.: "Cement-Matrix Composites for Thermal Engineering", Applied Thermal Engineering, 21 (2001), pp. $1607-1619$.

(5) Chung, D. D. L.: "Cement-Matrix Composites for Smart Structures", Smart Materials and Structures, 9: 4 (2000), pp. 389-401.

(6) Chung, D. D. L.: "Cement-Matrix Structural Nanocomposites", Metals and Materials International, 10: 1 (2004), pp. 55-67.

(7) Chung, D. D. L.: "Electrical Conduction Behavior of Cement-Matrix Composites", Journal of Materials Engineering and Performance, 11: 2 (2002), pp. 194-204.

(8) Chung, D. D. L.: "Functional Properties of Cement-Matrix Composites", Journal of Materials Science, 36 (2001), pp. $1315-1324$.

(9) Chung, D. D. L.: "Piezoresistive cement-based materials for strain sensing", Journal of Intelligent Materials Systems and Structures, 13: 9 (2002), pp. 599-609.

(10) Muthusamy, S.; Wang, S.; Chung, D. D. L.: "Unprecedented Vibration Damping with High Values of Loss Modulus and Loss Tangent, Exhibited by Cement-Matrix Graphite Network Composite", Carbon, 48 : 5 (2010), pp. 1457-1464 (2010).

(11) Zornoza, E.; Catalá, G.; Jiménez, F.; Andión, L. G.; Garcés, P.: "Electromagnetic interference shielding with Portland cement paste containing carbon materials and processed fly ash", Mater. Construcc., 60: 300 (2010), pp. 21-32. doi: 10.3989/mc.2010.51009.

(12) Alcaide, J. S.; Alcocel, E. G.; Puertas, F.; Lapuente, R.; Garcés, P.: "Carbon fibre-reinforced, alkali-activated slag mortars", Mater. Construcc., 57: 288 (2007), pp. 33-48.

(13) Alcaide, J. S.; Alcocel, E. G.; Vilaplana, E.; Cazorla, D.; Garcés. P.: "Mechanical characterization of Portland cement mortars containing petroleum or coal tar", Mater. Construcc., 57: 287 (2007), pp. 53-62.

(14) Li, J.; Vergne, M. J.; Mowles, E. D. et al.: "Surface functionalization and characterization of graphitic carbon nanofibers (GCNFs)", Carbon, 43 (2005), pp. 2883-2893.

(15) Nasibulina, I.; Anoshkin, V.; Shandakov, D. et al.: "Direct Synthesis of Carbon Nanofibers on Cement Particles", Transportation Research Record, 2142 (2010), pp. 96-101.

(16) Sánchez, F.; Ince, C.: "Microstructure and macroscopic properties of hybrid carbon nanofiber/silica fume cement composites", Composites Science and Technology, 69 (2009), pp. 1310-1318. 
(17) Yazdanbakhsh, A.; Grasley, Z.; Tyson, B. et al.: "Distribution of carbon nanofibers and nanotubes in cementitious composites", Transportation Research Record: Journal of the Transportation Research Board (2010), pp. 89-95.

(18) Metaxa, Z. S.; Konsta-Gdoutos, M. S.; Shah, S. P.: "Carbon Nanofiber-Reinforced Cement-Based Materials", Transportation Research Record, 2142 (2010), pp. 114-118.

(19) Kang, I. P.; Heung, Y. Y.; Kim, J. H.; Lee, J. W.; Gollapudi, R.; Subramaniam, S.; Narasimhadevara, S.; Hurd, D.; Kirikera, G. R.; Shanov, V.; Schulz, M. J.; Shi, D. L.; Boerio, J.; Mall, S.; Ruggles-Wren, M.: "Introduction to carbon nanotube and nanofiber smart materials", Composites Part B-Engineering, 37: 6 (2006), pp. 382-394.

(20) Gay, C.; Sánchez, F: "Performance of Carbon Nanofiber-Cement Composites with a High-Range Water Reducer", Transportation Research Record, 2142 (2010), pp. 109-113.

(21) Sánchez, F.; Zhang, L.; Ince, C.: "Multi-scale performance and durability of carbon nanofiber/cement composites", in: Bittnar, Z.; Bartos, P. J. M.; Nemecek, J. et al. (eds.): Nanotechnology in construction: proceedings of the NICOM3 (3rd International Symposium on Nanotechnology in Construction) (2009), Prague, Czech Republic, pp. 345-350.

(22) Bortz, D. R.; Merino, C.; Martín-Gullón, I.: "Carbon nanofibers enhance the fracture toughness and fatigue performance of a structural epoxy system", Composites Science and Technology, 71 (2011), pp. 31-38.

(23) Zornoza, E.; Garcés, P.; Payá, J.: "Corrosion rate of steel embedded in blended Portland and fluid catalytic cracking catalyst residue (FC3R) cement mortars", Mater. Construcc., 58: 292 (2008), pp. 27-43. doi: 10.3989/mc.2008.39006

(24) Zornoza E.; Payá, J.; Garcés, P.: "Chloride-induced corrosion of steel embedded in mortars containing fly ash and spent cracking catalyst", Corrosion Science, 50: 6 (2008), pp. 1567-1575. doi: 10.1016/j.corsci.2008.02.001

(25) Alcocel, E. G.; Garcés, P.; Martínez, J. J.; Payá, J.; Andión, L. G.: "Effect of sewage sludge ash (SSA) on the mechanical performance and corrosion levels of reinforced Portland cement mortars", Mater. Construcc., 56: 1 (2006), pp. 31-43.

(26) Zornoza, E.; Payá, J.; Garcés, P.: "Carbonation rate and reinforcing steel corrosion rate of OPC/FC3R/FA mortars under accelerated conditions", Advances in Cement Research, 21: 1 (2009), pp. 15-22. doi: 10.1680/adcr.2007.00008

(27) Zornoza, E.; Garcés, P.; Payá, J.; Climent, M. A.: "Improvement of the chloride ingress resistance of OPC mortars by using spent cracking catalyst", Cem. Concr. Res., 39: 2 (2009), pp. 126-139. doi: 10.1016/j.cemconres.2008.11.006

(28) Stern, M.; Geary, A. L.: "A theoretical analysis of the shape of polarization curves", Journal of Electrochemical Society, 104 (1957) p. 56. doi: $10.1149 / 1.2428473$

(29) Andrade, C.; González, J. A.: "Quantitative measurements of corrosion rate of reinforcing steels embedded in concrete using polarization resistance measurements", Werkst. Korros., 29 (1978) 515. doi: 10.1002/maco.19780290804 